\title{
Implementasi Profil Multimedia SMK Nurul Haromain Pujon
}

\author{
Soetam Rizky Wicaksono ${ }^{1 *}$, Didit Prasetyo Nugroho ${ }^{2}$ \\ ${ }^{1,2}$ Fakultas Sains dan Teknologi \\ ${ }^{1,2}$ Universitas Ma Chung, Villa Puncak Tidar N-01 Malang \\ *e-mail : soetam.rizky@machung.ac.id
}

\author{
Informasi Artikel \\ Diterima Redaksi : 8 Desember 2020 \\ Revisi Akhir : 2 Januari 2021 \\ Diterbitkan Online : 28 Januari 2021 \\ Kata Kunci: \\ Video, Multimedia, SMK Nurul Haromain
}

\section{Abstrak}

SMK Nurul terletak di Pujon, Kabupaten Malang yang berbatasan langsung dengan kotamadya Batu, juga memiliki lokasi yang cukup nyaman dengan dikelilingi oleh area persawahan serta pemandangan pegunungan, namun tetap dekat dengan akses jalan raya. SMK tersebut merupakan bagian dari Pondok Pesantren Nurul Haromain, sehingga proses belajar mengajar yang ada didalamnya memiliki integrasi dengan akhlak Al Quran dalam kehidupan sehari-hari. Meski telah berdiri lama, namun masih memiliki siswa antara 20 40 per tahun dengan dua jurusan yang dimiliki, yakni tata busana dan Teknik Komputer Jaringan, maka pihak sekolah berniat untuk melakukan inovasi dalam proses promosi penerimaan peserta didik baru (PPDB) di tahun ajaran berikutnya. Salah satu proses promosi yang akan ditempuh adalah melalui pemasangan iklan dan sebaran informasi melalui internet.

Profil multimedia berupa video singkat dengan alokasi waktu antara 3 hingga 5 menit bertujuan untuk menunjang kepentingan proses promosi dalam PPDB. Video profile juga dapat menjadi sarana komunikasi satu arah yang sangat efektif bagi pihak sekolah dengan stakeholders seperti dewan pengawas sekolah, pihak yayasan maupun orang tua siswa. Selain itu juga dapat menjadi sarana pengikat bagi para alumni untuk bisa menyebarluaskan informasi yang tepat mengenai keunggulan kompetitif atau competitive advantage dari almamater kepada khalayak secara luas. Sehingga hal tersebut dapat menjadi justifikasi mengenai kepentingan pembuatan video profile ini bagi SMK Nurul Haromain..

\section{PENDAHULUAN}

SMK Nurul Haromain merupakan SMK yang memiliki profil cukup unik. Selain terletak di Pujon, Kabupaten Malang yang berbatasan langsung dengan kotamadya Batu, sehingga dikelilingi oleh puluhan tempat wisata, SMK tersebut juga memiliki lokasi yang cukup nyaman dengan dikelilingi oleh area persawahan serta pemandangan pegunungan, namun tetap dekat dengan akses jalan raya. Keunikan lainnya adalah karena SMK tersebut merupakan bagian dari Pondok Pesantren Nurul Haromain, sehingga proses belajar mengajar yang ada didalamnya memiliki integrasi dengan akhlak Al Quran dalam kehidupan sehari-hari.
Meski telah berdiri sejak tahun 2011, SMK tersebut masih memiliki siswa yang tidak terlalu banyak. Dengan kisaran jumlah siswa baru antara $20-40$ per tahun dengan dua jurusan yang dimiliki, yakni tata busana dan Teknik Komputer Jaringan, maka pihak sekolah berniat untuk melakukan inovasi dalam proses promosi penerimaan peserta didik baru (PPDB) di tahun ajaran berikutnya. Salah satu proses promosi yang akan ditempuh adalah melalui pemasangan iklan dan sebaran informasi melalui internet.

Sebaran informasi yang dimaksudkan untuk kepentingan PPDB juga telah direstui sebagai salah satu alokasi dana BOS yang diperbolehkan berdasarkan Permendikbud no. 1 tahun 2018 serta Permendikbud nomor 
26 tahun 2017. Sehingga dapat dipastikan bahwa aktifitas pembuatan profil multimedia adalah salah satu kegiatan penting bagi pihak sekolah. Sedangkan di sisi lain, alokasi dana BOS untuk sekolah swasta yang sudah pasti lebih kecil dibandingkan sekolah negeri menyebabkan pihak SMK Nurul Haromain menjadi kesulitan dalam mengimplementasikan hal tersebut.

Profil multimedia berupa video singkat dengan alokasi waktu antara 3 hingga 5 menit (sebagai batas dari tingkat fokus manusia di internet [1]) merupakan salah satu kebutuhan pokok bagi pihak sekolah saat ini. Selain dapat menunjang kepentingan proses promosi dalam PPDB, khususnya saat melakukan kunjungan ke sekolah menengah pertama, juga dapat menjadi profil yang ditayangkan secara masif melalui kanal Youtube ataupun media sosial lain seperti Facebook dan Instagram. Hal ini berdasarkan studi empiris yang menyebutkan tingkat keterikatan pemirsa dalam sebaran informasi di sosial media dengan format video sangatlah efektif [2], [3].

Promosi dengan menggunakan video secara empiris mampu meningkatkan engagement dari calon pelanggan [4]-[6], dalam kasus ini adalah calon siswa maupun calon orang tua siswa. Sehingga proses pembuatan video ini menjadi urgensi bagi pihak pengelola sekolah.

Di sisi lain, video profile juga dapat menjadi sarana komunikasi satu arah yang sangat efektif bagi pihak sekolah dengan stakeholders seperti dewan pengawas sekolah, pihak yayasan maupun orang tua siswa. Selain itu juga dapat menjadi sarana pengikat bagi para alumni untuk bisa menyebarluaskan informasi yang tepat mengenai keunggulan kompetitif atau competitive advantage dari almamater kepada khalayak secara luas. Sehingga hal tersebut dapat menjadi justifikasi mengenai kepentingan pembuatan video profile ini bagi SMK Nurul Haromain.

\section{METODE}

Di dalam pelaksanaan pengabdian ini, langkah yang ditempuh oleh tim pendamping dengan dukungan dari sebagai mitra dapat dijabarkan sebagai berikut:
1. Langkah pertama adalah dengan melakukan proses pendekatan serta brainstorming dengan pihak sekolah sekaligus mengumpulkan data keunggulan kompetitif.

2. Langkah kedua adalah melakukan proses analisis awal untuk pembuatan video profile.

3. Langkah berikutnya adalah melakukan proses shooting ke lokasi sekolah, termasuk didalamnya melakukan profiling dengan pihak sekolah

4. Langkah keempat adalah melakukan editing serta kompilai hasil shooting untuk menjadi video profile serta mendiseminasikan ke pihak sekolah

5. Langkah terakhir adalah melakukan evaluasi akhir sekaligus pelaporan dan penerbitan karya ilmiah ke jurnal yang telah ditargetkan sebelumnya

\section{HASIL DAN PEMBAHASAN}

Di dalam pelaksanaan pengabdian ini, langkah yang ditempuh oleh tim pendamping dengan dukungan dari sebagai mitra dapat dijabarkan sebagai berikut:

1. Langkah pertama adalah dengan melakukan proses brainstorming dengan pihak SMK, khususnya kepala sekolah dan guru yang menjadi penanggung jawab untuk kegiatan promosi. Aktifitas ini dilakukan pada bulan Desember 2019, dan dilakukan secara online hingga mendapatkan profil serta competitive advantage yang ingin ditampilkan di dalam video profile.

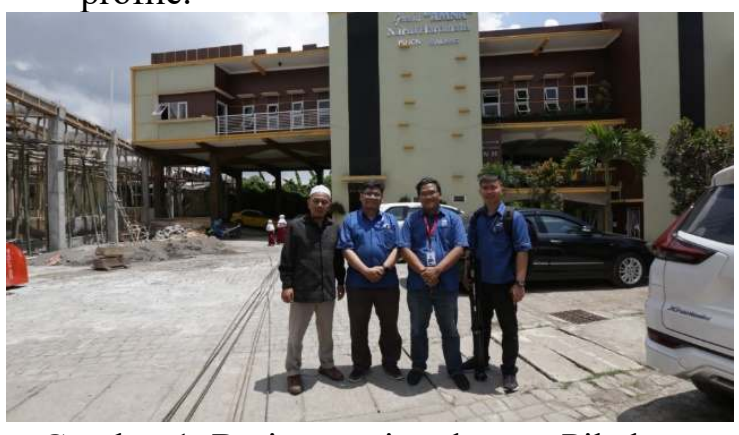

Gambar 1. Brainstorming dengan Pihak SMK

2. Langkah kedua adalah melakukan proses analisis awal untuk video profile. Di dalam proses ini dengan mengadakan observasi lapangan serta lokasi dan interview singkat para pemangku kepentingan. 
3. Langkah berikutnya adalah melakukan proses shooting di lingkungan SMK yang telah diselesaikan pada tanggal 20 Januari 2020 , dengan surat tugas nomor Nomor:

001/MACHUNG/ST/I/2020

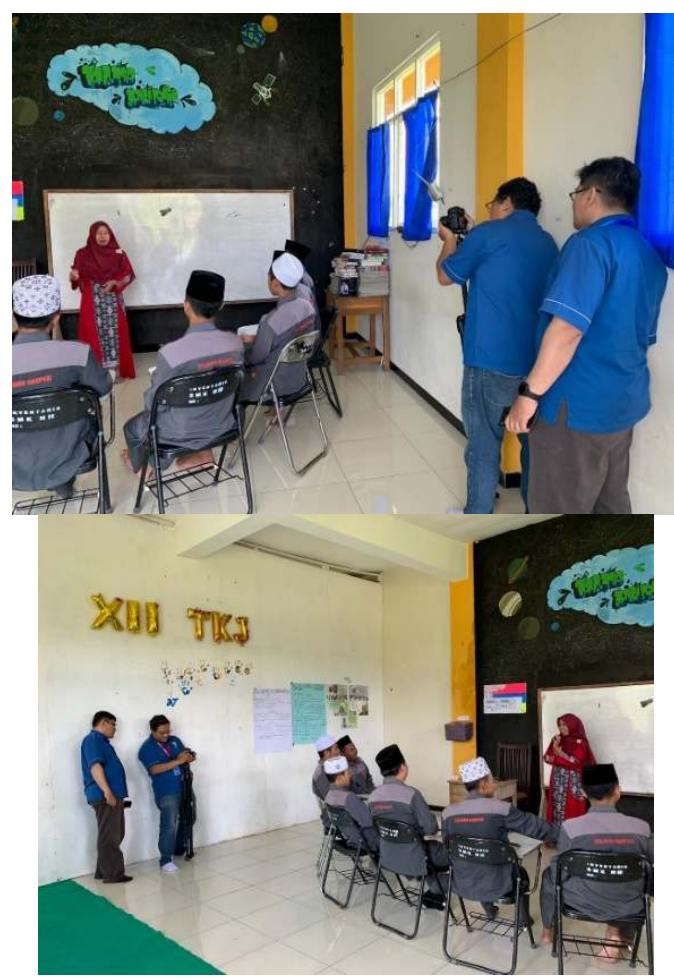

Gambar 2. Proses Shooting

4. Hasil editing dan finalisasi diselesaikan pada tanggal 20 Februari 2020, dan telah diupload ke youtube oleh pihak SMK dengan alamat berikut: https:/www.youtube.com/watch?v $=9 \mathrm{qNs} X D h Z R N 0$

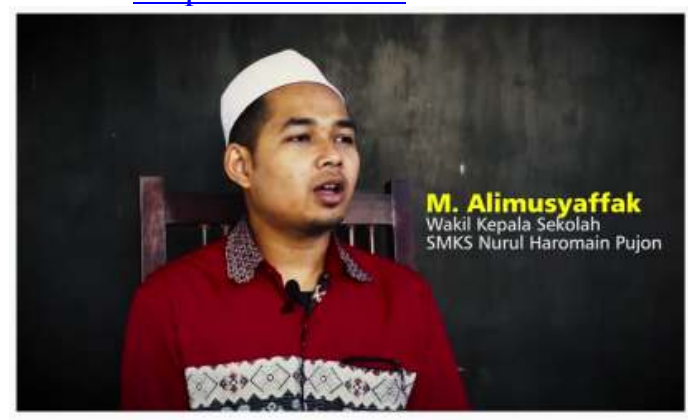

SMK Nurul Haromain Pujon, Sekolah kejuruan berbasis pesantren.

Gambar 3. Screenshot Hasil Upload

Langkah terakhir adalah melakukan evaluasi akhir sekaligus pelaporan dan penerbitan karya ilmiah ke jurnal yang telah ditargetkan sebelumnya.

\section{KESIMPULAN}

Berdasarkan hasil pengabdian masyarakat yang telah dilaksanakan, maka dapat dijabarkan beberapa kesimpulan sebagai berikut:

1. Proses analisis dan pembuatan video profile telah selesai dilakukan

2. Hasil video profile untuk sebaran informasi telah selesai didiseminasikan ke pihak yang berkepentingan yakni mitra SMK Nurul Haromain dan diunggah ke youtube

3. Luaran publikasi telah selesai dan telah selesai dipublikasikan ke dalam jurnal yang bersesuaian

Sedangkan saran dari hasil kegiatan ini adalah sebagai berikut:

1. Hasil dari pelaksanaan pengabdian ini dapat dilanjutkan dengan proses lain yang lebih dibutuhkan pihak sekolah, seperti misalnya profil untuk guru dan kegiatan ekstrakurikuler serta kegiatan terpadu dari pondok pesantren sebagai competitive advantage

2. Luaran publikasi dapat dijadikan buku ajar, khususnya untuk program studi DKV, karena dalam aktifitas ini tercantum lengkap langkah detail untuk pembuatan video profile di ruang lingkup sekolah.

\section{REFERENSI}

[1] E. Fisherman, "How long should your next video be?," Wistia, 2016. [Online]. Available: https://wistia.com/learn/marketing/o ptimal-video- length\%0AFisherma.

[2] N. Serapio and B. Fogg, "Designing for video engagement on social networks," in Proceedings of the 4th International Conference on Persuasive Technology - Persuasive '09, 2009, p. 1.

[3] S. Gunelius, 30-Minutes SOCIAL MEDIA Marketing. 2011.

[4] L. Rune and H. Vinberg, "Content is King Communication Effects of Viral Video Marketing," Stockholm School of Economics, 2009.

[5] T. Boomika Imayavarthini and Muruganramu, "A study on digital marketing," Int. J. Psychosoc. Rehabil., vol. 24, no. 4, pp. 2784- 
2789, 2020.

[6] K. Boman and K. Raijonkari, "Online Video as a Marketing Tool A Quantitative Survey on Video Marketing Habits," JAMK University of Applied Sciences, 2017. 